\title{
The Facilities of Badminton Field in West Sumatera
}

\author{
Endang Sepdanius
}

Faculty of Sport Science, Universitas Negeri Padang

\begin{abstract}
This study aims to reveal the suitability of badminton field facilities in West Sumatera based on badminton regulatory indicators. The criteria used are the criteria issued by the Badminton game rules of the World Federation. The method in this research uses quantitative methods with a descriptive approach. Data were collected by conducting direct observations in the field and interviews with field owners. The results of the research were that $78 \%$ of the field meets the criteria related to the width of the field line, $81 \%$ was related to the height of the pole, $73 \%$ was related to the depth of the net, $78 \%$ was related to the width of the net, $71 \%$ was related to the net height in the middle of the field, $79 \%$ was related to the net height at double pile area, 34\% related to no gap between the netting and the netting posts, $90 \%$ to the length of the court, $86 \%$ was related to the width of the doubles court, $77 \%$ to the width of the single court, $75 \%$ to the net distance tothe short service line, $79 \%$ to the long service area of the singles. Information from interviews found that carpet-based fields met the requirements of the field because they were installed directly by the consultant, while fields with other materials only expected information from the internet and did not get clear source information.
\end{abstract}

Keyword: facilities, badminton,

\section{Introduction}

Sports facilities are an important part of the development of sports and health achievements. Adequate facilities are an important factor in fostering community motivation to be actively involved in sports activities. There are many types of sports activities carried out by the community for various purposes, one of which is badminton. In Indonesia badminton is a popular sport and the majority of Indonesians play this sport for the purpose of achievement, health and recreation. As an achievement sport, Indonesia is a country that is highly reckoned with in international competitions. This is inseparable from sustainable and tiered nurseries in every province in Indonesia.

The tiered nursery carried out by PBSI is very well planned, however, this nursery is still dominated by people on the island of Java. The development on the island of Java is slightly more advanced than in the provinces outside the island of Java. Like on the island of Sumatera for example. The map of success in getting the title is still alternating between South Sumatera, Riau and West Sumatera. However, in the last 1 period the presentation of West Sumatera was very unexpected. Finally, in the preliminary event for PON 2021, West Sumatera was unable to send its athletes because they could not compete with athletes from other provinces in the Sumatera region. The problems that occur in West Sumatera are not only from guidance and management. Another factor that also plays an important role is badminton sports facilities(Helen Purnama Sari, 2017). In terms of quantity, in West Sumatera, there is a positive growth in the number of fields. However, the problem is that the fields that were built follow the national standards issued by PBSI or not.

National Sports Standardization aims to ensure the quality of the implementation of the national sports system through the achievement of National Sports Standards(Peraturan Pemerintah Republik Indonesia, 
2007).Facilities are the most important aspect in supporting achievement. In sports activities, facilities are very vital because they are related to the legitimacy of a game in the sport(Lingga \& Setyawan Farid Helmi, 2019). The importance of accuracy in implementing all facilities in accordance with existing standards are mandatory for the organizers so that the match runs as it should(Pambudi, 2020).

Each sport has basic rules and bylaws which are arranged in its regulations related to sports that must be obeyed when providing sports facilities. Not only as a complement to the game, sports facilities are also a reference for the continuation of the game fairly, not detrimental to one group. Facilities that are not standardized or not in accordance with standards can be detrimental to players and this can cause conflicts between players. Badminton matches are usually carried out on fields that already have quality standards by referring to the guidelines of the overseeing organization. Because the competition is required so as not to cause errors that can burden the organizing committee. On the contrary, in certain circumstances, namely when training or when the field is used as a means of recreational and health sports activities, the sports facilities used are often neglected as inappropriate as they should be. This habit usually affects the quality of the game and the automation that is built up during practice and will be carried over during the match.

PBSI in the bylaws on badminton regulations has issued guidelines in installing badminton sports facilities. Related to the length of the field, width, height of the net post, net height in the middle and edge and width of the field line(PBSI, 2020)(BWF, 2016). As for those related to field facilities that are often neglected, 1)The width of the field line is $40 \mathrm{~mm}$ or $4 \mathrm{~cm}, 2$ ) The poles are 1.55 meters high from the surface of the court, 3) The net must have a depth of $760 \mathrm{~mm}$, 4) The net must be at least 6.1 meters wide, 5) The top of the net is from the surface the pitch must be 1.524 meters in the middle of the court, 6) The top of the net from the surface of the court must be 1.55 meters above the side line for doubles, 7) There shall be no gaps between the ends of the netting and the posts if necessary, the full depth of the netting at the ends must be tied to the poles, 8) Field length is 13.4 meters, 9) Field width for doubles is 6.1 meters, 10) Field width for singles is 5.1 meters, 11) Net distance with short service warranty is 1.98 meters, 12) Length of area The rear between the rear short service line and the long back service line is $720 \mathrm{~mm}$ (excluding the $40 \mathrm{~mm} / 4 \mathrm{~cm}$ line size).

\section{Method}

This research is a quantitative study that aims to obtain data related to the suitability of size and completeness of field facilities in the West Sumatera Province of Indonesia.

\section{Population and Sample}

The population is all badminton courts throughout West Sumatera. The sample in this study was a badminton field that was reached by the data collection teams in their respective regions. There are 73 fields sampled in this study. The following is shown the data

Table 1. Number of fields sampled

\begin{tabular}{|c|c|c|}
\hline No. & Regency in West Sumatera & f \\
\hline 1 & Religion & 3 \\
\hline 2 & Batusangkar & 1 \\
\hline 3 & Bukittinggi & 2 \\
\hline 4 & Dharmasraya & 3 \\
\hline 5 & Pariaman City & 1 \\
\hline 6 & 50 Kota & 7 \\
\hline 7 & Padang & 20 \\
\hline 8 & Padang Pariaman & 4 \\
\hline 9 & Pasaman & 4 \\
\hline 10 & West Pasaman & 4 \\
\hline 11 & Payakumbuh & 5 \\
\hline 12 & South Pesisir & 7 \\
\hline
\end{tabular}




\begin{tabular}{|c|c|c|}
\hline 13 & Sijunjung & 1 \\
\hline 14 & Solok & 5 \\
\hline 15 & Solok Kabupten & 2 \\
\hline 16 & South Solok & 2 \\
\hline 17 & Tanah Datar & 2 \\
\hline & $\mathrm{n}=$ & 73 \\
\hline
\end{tabular}

\section{Instrument}

The instrument used are 12 field criteria based on badminton competition(BWF, 2016). The following describes some of the criteria used as an instrument.

Table 2. 12 field criteria based on badminton competition

\begin{tabular}{|c|c|}
\hline No. & Criteria \\
\hline 1 & Field line width of $40 \mathrm{~mm}$ or $4 \mathrm{~cm}$ \\
\hline 2 & The poles are 1.55 meters high from the surface of the field \\
\hline 3 & The netting must have a depth of $760 \mathrm{~mm}$ \\
\hline 4 & The netting must be at least 6.1 meters wide \\
\hline 5 & $\begin{array}{l}\text { The top of the net from the court's surface must be } 1.524 \text { meters in the center of } \\
\text { the court }\end{array}$ \\
\hline 6 & $\begin{array}{l}\text { The top of the net from the court surface must be } 1.55 \text { meters above the side } \\
\text { line for doubles }\end{array}$ \\
\hline 7 & $\begin{array}{l}\text { There should be no gaps between the ends of the netting and the posts. If } \\
\text { necessary, the full depth of the netting at the ends must be tied to the posts }\end{array}$ \\
\hline 8 & The length of the field is 13.4 meters \\
\hline 9 & The width of the field for the double is 6.1 meters \\
\hline 10 & The pitch width for singles is 5.1 meters \\
\hline 11 & The net distance with a short service warranty is 1.98 meters \\
\hline 12 & $\begin{array}{l}\text { The length of the back area between the rear short service line and the long } \\
\text { back service line is } 720 \mathrm{~mm} \text { (not including the } 40 \mathrm{~mm} / 4 \mathrm{~cm} \text { line size) }\end{array}$ \\
\hline
\end{tabular}

\section{Data collection technique}

The data collection technique was carried out by directly descending the field with the help of a data collection team. Prior to this, data collectors were given training through zoom meting on how to get data and how to fill in the instruments that had been provided. In addition, the data collectors are also equipped with an interview guide to conduct interviews with field managers about the sources of information used by the managers to carry out field installations.

\section{Data analysis technique}

The data analysis technique uses descriptive analysis which describes the actual data. The data are processed to obtain the amount, average, percentage, and standard deviation.

\section{Results \\ Data Description}

Table 3. Percentage of items assessed as a whole

\begin{tabular}{|c|c|c|c|c|c|}
\hline No. & Item & $\sum$ & Mean & $\%$ & Stdev \\
\hline 1 & Field line width of $40 \mathrm{~mm}$ or $4 \mathrm{~cm}$ & 57 & 0.78 & $78 \%$ & 0.42 \\
\hline 2 & The poles are 1.55 meters high from the surface of the field & 59 & 0.81 & $81 \%$ & 0.40 \\
\hline 3 & The netting must have a depth of $760 \mathrm{~mm}$ & 53 & 0.73 & $73 \%$ & 0.45 \\
\hline 4 & The netting must be at least 6.1 meters wide & 57 & 0.78 & $78 \%$ & 0.42 \\
\hline 5 & $\begin{array}{l}\text { The top of the net from the court's surface must be } 1.524 \text { meters in the center of } \\
\text { the court }\end{array}$ & 52 & 0.71 & $71 \%$ & 0.46 \\
\hline
\end{tabular}




\begin{tabular}{|c|l|c|c|c|c|}
\hline 6 & $\begin{array}{l}\text { The top of the net from the court surface must be } 1.55 \text { meters above the side line } \\
\text { for doubles }\end{array}$ & 58 & 0.79 & $79 \%$ & 0.41 \\
\hline 7 & $\begin{array}{l}\text { There should be no gaps between the ends of the netting and the posts. If } \\
\text { necessary, the full depth of the netting at the ends must be tied to the posts }\end{array}$ & 25 & 0.34 & $34 \%$ & 0.48 \\
\hline 8 & The length of the field is 13.4 meters & 66 & 0.90 & $90 \%$ & 0.30 \\
\hline 9 & The width of the field for the double is 6.1 meters & 63 & 0.86 & $86 \%$ & 0.35 \\
\hline 10 & The pitch width for singles is 5.1 meters & 56 & 0.77 & $77 \%$ & 0.43 \\
\hline 11 & The net distance with a short service warranty is 1.98 meters & 55 & 0.75 & $75 \%$ & 0.43 \\
\hline 12 & $\begin{array}{l}\text { The length of the back area between the rear short service line and the long back } \\
\text { service line is 720mm (not including the 40mm / 4cm line size) }\end{array}$ & 58 & 0.79 & $79 \%$ & 0.41 \\
\hline
\end{tabular}

The results obtained are that $78 \%$ of the field meets the criteria related to field line width, $81 \%$ is related to pole height, $73 \%$ is related to net depth, $78 \%$ is related to net width, $71 \%$ is related to net height in the middle of the field, $79 \%$ is related to net height at double court area, 34\% related to no gap between netting and netting posts, $90 \%$ to court length, $86 \%$ to double court width, $77 \%$ to single court width, $75 \%$ to net distance to service line short, $79 \%$ related to the long service area for singles. For more details, it can be seen in the following graph 1 :

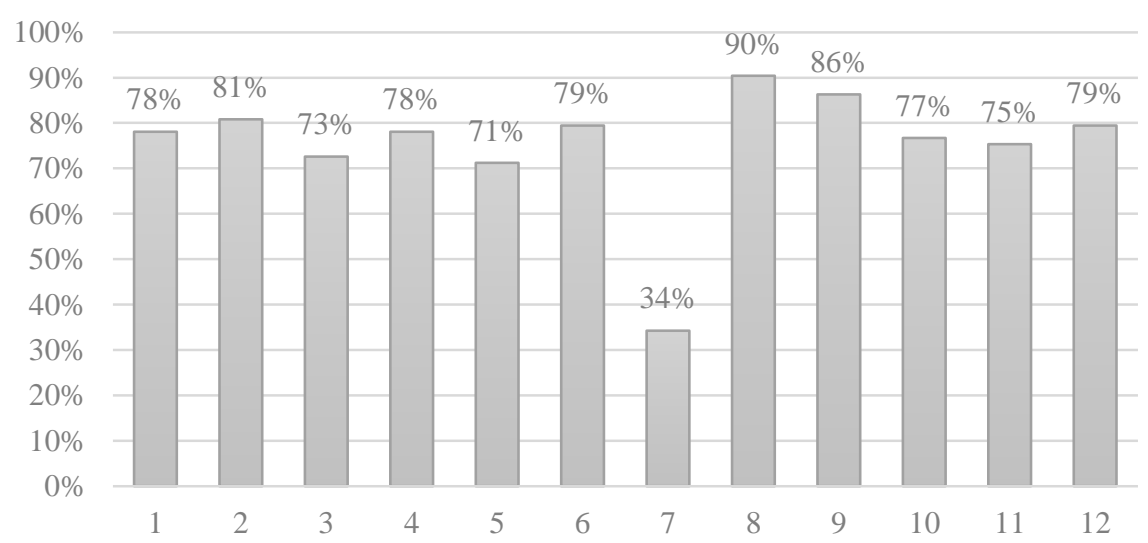

Graph 1. Fultillment of the Badminton Field Criteria in West Sumatera is based on standards

\section{Carpet and Non-Carpet Field}

The following shows comparison data between carpet-based fields and other field-based materials against 12 criteria. The following is shown in table 4.

Table 4. Comparison of the carpet field with other materials

\begin{tabular}{|c|c|c|c|c|c|c|c|c|c|}
\hline \multirow[t]{2}{*}{ No. } & \multirow[t]{2}{*}{ Item } & \multicolumn{4}{|c|}{ Carpet } & \multicolumn{4}{|c|}{ Not a carpet } \\
\hline & & $\sum$ & Mean & $\%$ & Stdev & $\sum$ & Mean & $\%$ & Stdev \\
\hline 1 & Field line width of $40 \mathrm{~mm}$ or $4 \mathrm{~cm}$ & 44 & 0.96 & $96 \%$ & 0.21 & 13 & 0.48 & $48 \%$ & 0.51 \\
\hline 2 & The poles are 1.55 meters high from the surface of the field & 38 & 0.83 & $83 \%$ & 0.38 & 21 & 0.78 & $78 \%$ & $\overline{0.42}$ \\
\hline 3 & The netting must have a depth of $760 \mathrm{~mm}$ & 35 & 0.76 & $76 \%$ & 0.43 & 18 & 0.67 & $67 \%$ & $\overline{0.48}$ \\
\hline 4 & The netting must be at least 6.1 meters wide & 39 & 0.85 & $85 \%$ & 0.36 & 18 & 0.67 & $67 \%$ & 0.48 \\
\hline 5 & $\begin{array}{l}\text { The top of the net from the court's surface must be } 1.524 \text { meters in the } \\
\text { center of the court }\end{array}$ & 32 & 0.70 & $70 \%$ & 0.47 & 20 & 0.74 & $74 \%$ & 0.45 \\
\hline 6 & $\begin{array}{l}\text { The top of the net from the court surface must be } 1.55 \text { meters above the } \\
\text { side line for doubles }\end{array}$ & 38 & 0.83 & $83 \%$ & 0.38 & 20 & 0.74 & $74 \%$ & 0.45 \\
\hline 7 & $\begin{array}{l}\text { There should be no gaps between the ends of the netting and the posts. If } \\
\text { necessary, the full depth of the netting at the ends must be tied to the posts }\end{array}$ & 17 & 0.37 & $37 \%$ & 0.49 & 8 & 0.30 & $30 \%$ & 0.47 \\
\hline 8 & The length of the field is 13.4 meters & 43 & 0.93 & $93 \%$ & 0.25 & 23 & 0.85 & $85 \%$ & $\overline{0.36}$ \\
\hline 9 & The width of the field for the double is 6.1 meters & 39 & 0.85 & $85 \%$ & 0.36 & 24 & 0.89 & $89 \%$ & 0.32 \\
\hline 10 & The pitch width for singles is 5.1 meters & 38 & 0.83 & $83 \%$ & 0.38 & 18 & 0.67 & $67 \%$ & 0.48 \\
\hline 11 & The net distance with a short service warranty is 1.98 meters & 36 & 0.78 & $78 \%$ & 0.42 & 19 & 0.70 & $70 \%$ & 0.47 \\
\hline
\end{tabular}




\begin{tabular}{|c|l|l|l|l|l|l|l|l|}
\hline 12 & $\begin{array}{l}\text { The length of the back area between the rear short service line and the } \\
\text { long back service line is } 720 \mathrm{~mm} \text { (not including the } 40 \mathrm{~mm} / 4 \mathrm{~cm} \text { line size) }\end{array}$ & 38 & 0.83 & $83 \%$ & 0.38 & 20 & 0.74 & $74 \%$ \\
\hline
\end{tabular}

Based on the description of the data above, the basic material of the carpet is above $70 \%$ fulfilling the standard. Only one item that is still below $37 \%$ is related to the density of the net with the pole. Unlike the field that is not made from carpet. Based on the description of the data in table 4 above, there are still two items that are made from other than carpet, namely item number 1 , which is $48 \%$ related to the width of the field line and item No.7, which is $30 \%$ related to the density of the net with the pole.

The following shows a comparison between a court made from carpet with a field made from non-carpet based on 12 items of Indonesian badminton national standards and refers to badminton regulations. The comparison is shown in Figure 2 below:

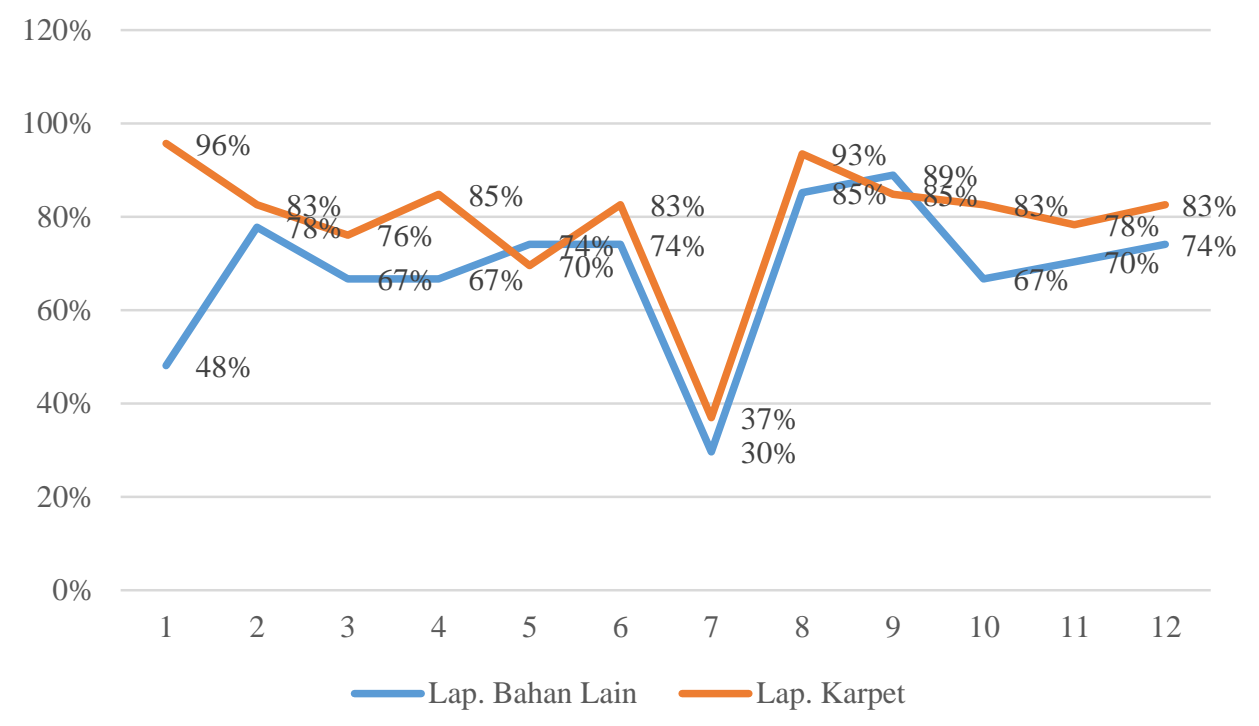

Figure 2. Comparison of Completeness Between Carpet and Other Materials

Based on the comparisons made, it can be seen that point one is a field line which is a very significant differentiator. $95 \%$ of carpet-based courts have a court line width that complies with badminton regulatory standards. Whereas for other fields, it only has a $48 \%$ suitability. Thus, there are vastly different between the fields of these two different materials.

Based on the results obtained, in addition to measuring directly, interviews were also conducted with field owners related to the construction of the field. The information obtained explains that some fields with carpet-based materials have line sizes, widths and lengths according to the standards, because the work was carried out by field consultants. Meanwhile, with regard to the net, the owners do not follow badminton rules so that they install the net only by getting information from the internet without a clear source. So, the net height in the middle of the court and at the edge of the court is often not appropriate. In addition, there are often gaps between the net and the net posts. The field owner does not understand that the net must be attached to the post so that there is no gap between the net and the post. Then, the owners do not understand the position of the net poles. They don't know that the net post is an extension of the double section edge line. So that the pole is the area of the field. Therefore, there should be no gaps between the netting and the field poles.

Not as good as in a carpet-based field, a field with other basic materials has many shortcomings. The results showed that the field owner collected information related to the size of the field and other facilities, only expecting information from the internet and asking people around him. So that the information obtained is not proven true because it does not come from a credible source. 


\section{Discussion}

A lot of research information explains the importance of adequate sports facilities that support the specific results to be achieved. Among them, sports facilities play an important role in understanding and improving the educational process(Purnama \& Siliwangi, 2017). Then adequate sports facilities are used to meet the basic needs of the community for sports(Jessica, 2020). Furthermore, sports and recreational facilities are also developed as a place to relax, unwind, and be free to express in them which are manifested in sports and recreation activities.(Putra \& Lianto, 2020). Other research shows that the high public interest in the use of sports facilities is influenced by the needs of the community and the ease of visiting and utilizing these facilities(Valianto \& M. Sirait, 2018) and sports facilities with many kinds to become a variety of sports activities for the community(Utsman Syah Amrullah et al., 2020). On the other hand, another study found that schools with inadequate sports facilities led to a statistically significant reduction in physical activity participation during adulthood but, on the other hand, found no evidence that inadequate sports facilities worsened the level of physical and mental health, lifestyle or socioeconomic status of adults(Black et al., 2019). From several explanations related to these sports facilities, it is concluded that sports facilities affect the ultimate goal of providing these facilities. These sports facilities can be used to support education, achievement and public health. However, behind it all, it is important that there are standards that need to be followed by facility providers that refer to the respective sports regulations.

Badminton is a sport that is very popular among Indonesians. This sport is often used as a means of recreation to achieve an adequate degree of health. So many fields are provided to be visited and used by the community for recreational sports. This activity is for health purposes only and to build friendship between people. The existence of this recreational facility is expected to generate a motivation for the community to exercise and socialize as well as foster the next generation who likes sports(Kurniawan \& Susilo, 2017). In addition, accessibility is a multidimensional concept that is integrated with the concepts of education, finance and geography(Karusisi et al., 2013). The success of the use of sports facilities depends on the choice of policies related to the use of sports infrastructure(Iversen \& Cuskelly, 2015).

On the other hand, the next generation in badminton is born from fields that provide adequate training services. Fields that have standard facilities are an integral part of improving athletes' abilities(Irawan, 2017). Habits that are carried out as a result of field facilities can be a trigger for problems that come when competing. Therefore, it is very important to pay attention to all the facilities associated with the badminton court that may influence the development of athletes.

From the results obtained, mostly related to the net and poles, the results were far from expected. The average field in West Sumatera does not meet this criterion. The existing field does not pay attention to the fact that the net with poles should not have gaps, but the results in the field are very contradictory to this. In the refereeing rules issued by PBSI it states that every field that holds a match must meet the criteria for the field standard. One is that there is no gap between the net and the post. However, in reality every field used for training and sparring does not comply with this rule, so the atmosphere of play between training and competing is different. Can be,

Another fundamental thing is based on the information obtained from interviews obtained from field owners and field managers that there are two different versions, namely a field with carpet facilities and a field other than a carpet. In the carpet field, the average percentage value obtained is better than the percentage value from fields other than carpets. This is influenced by the installation of carpets carried out by field consultants so that they have followed badminton regulations. However, there are still some items that are not yet complete. The very significant thing that looks different is that in the first point related to the width of the field line, it is very striking between the carpeted field and the other based fields. The carpet pitch has a better percentage accuracy compared to the pitch of other materials.

Based on the explanation above, the importance of coordination between sports facility providers in providing sports facilities refers to the sports regulations so that they do not violate the facilities of the facility which can harm its users. Adequate facilities can provide comfort to users and users can achieve 
good performance(Samudin et al., 2017). There is a strong relationship between the adequacy or completeness of facilities on the sports field and the number of participants involved in a sports club(Elmose- Østerlund \& Iversen, 2020). Other results show that the sporting competition is still inadequate in the sport of badminton in the state(Ekuri, 2018). This is an important concern for organizers to pay more attention to the sports being contested. On the other hand, in other countries Badiminton is a part of the sport which includes a complete category with facilities that meet the standards(Onojohwevwo et al., 2015).

\section{Conclusions}

Based on the results and discussion, there were components that are still below the required criteria, namely related to the gap between the net and the post. This is due to the lack of information received by field owners regarding the completeness of the facilities. It is advisable for field owners to obtain information to be directly contacted by the sports organizations that oversee it.

\section{Reference}

1. Black, N., Johnston, D. W., Propper, C., \& Shields, M. A. (2019). The effect of school sports facilities on physical activity, health and socioeconomic status in adulthood. Social Science and Medicine, 220. https://doi.org/10.1016/j.socscimed.2018.10.025

2. BWF. (2016). Laws -Badminton Part II -Section $1 A$ Laws of Badminton. http://system.bwf.website/documents/folder_1_81/Regulations/Laws/Part II Section 1A - Laws of Badminton - June 2016 Revised 2.pdf

3. Ekuri, P. E. (2018). Standard Facilities and Equipment as Determinants of High Sports Performance of Cross River State at National Sports Festival. Journal of Public Administration and Governance, 8(2). https://doi.org/10.5296/jpag.v8i2.13177

4. Elmose-Østerlund, K., \& Iversen, E. B. (2020). Do public subsidies and facility coverage matter for voluntary sports clubs? Sport Management Review, 23(2). https://doi.org/10.1016/j.smr.2019.03.007

5. Helen Purnama Sari, O. W. K. H. \& T. H. (2017). Evaluasi Program Pembinaan Atlet Pekan Olahraga Nasional Cabang Olahraga Bulu Tangkis Provinsi Sumatera Selatan. Journal of Physical Education and Sports, 6(3), 261-265.

6. Irawan, R. (2017). Studi Kelayakan Fasilitas Sarpras Olahraga Indoor di FIK UNNES. Jurnal Penjakora, 4(1).

7. Iversen, E. B., \& Cuskelly, G. (2015). Effects of different policy approaches on sport facility utilisation strategies. Sport Management Review, 18(4). https://doi.org/10.1016/j.smr.2014.12.004

8. Jessica, J. (2020). Fasilitas Olahraga Interaktif Di Rawa Bunga. Jurnal Sains, Teknologi, Urban, Perancangan, Arsitektur (Stupa), 2(2), 2003. https://doi.org/10.24912/stupa.v2i2.8549

9. Karusisi, N., Thomas, F., Méline, J., \& Chaix, B. (2013). Spatial accessibility to specific sport facilities and corresponding sport practice: The RECORD Study. International Journal of Behavioral Nutrition and Physical Activity, 10. https://doi.org/10.1186/1479-5868-10-48

10. Kurniawan, P., \& Susilo, N. (2017). Fasilitas Olahraga Rekreatif di Surabaya. Jurnal Dimensi Arsitektur, 1(1).

11. Lingga, P., \& Setyawan Farid Helmi. (2019). Manajemen Pengelolaan Fasilitas Olahraga Milik Pemerintah Kabupaten Ngawi Tahun 2018. Jurnal Pendidikan Modern, 5(1), 32-41. https://doi.org/10.37471/jpm.v5i1.65

12. Onojohwevwo, S., Diejomaoh, E., \& Akarah, E. (2015). Availability of Facilities and Equipment for Sports Administration at the Local Government Areas of Delta State , Nigeria. 4(2), 307-312. https://doi.org/10.5901/ajis.2015.v4n2p307

13. Pambudi, D. K. (2020). Analisis Standarisasi Fasilitas Gedung Olahraga Universitas Negeri Yogyakarta. Medikora, 19(1), 46-52. https://doi.org/10.21831/medikora.v19i1.30887

14. PBSI. (2020). Anggaran Dasar dan Anggaran Rumah Tangga PBSI. November, 1-13.

15. Peraturan Pemerintah Republik Indonesia. (2007). Peraturan Pemerintah Republik Indonesia Nomor 16 Tahun 2007 Tentang Penyelenggaraan Keolahragaan. 1-56.

16. Purnama, S., \& Siliwangi, U. (2017). Pengaruh manajemen fasilitas olahraga dan layanan guruterhadap efektivitas pendidikan jasmani olahraga dankesehatan (Studi Pada Sekolah Menengah Atas Negeri di Kota Tasikmalaya). Jurnal Sport Area, 105-114. 
17. Putra, A. A., \& Lianto, F. (2020). Desain Fasilitas Olahraga Dan Rekreasi Dengan Pendekatan Kanonis Di Duri Kepa, Jakarta. Jurnal Sains, Teknologi, Urban, Perancangan, Arsitektur (Stupa), 2(2), 2169. https://doi.org/10.24912/stupa.v2i2.8621

18. Samudin, T, E. Y., \& Sasmito, A. (2017). Semarang Sport Center (Dengan pendekatan konsep penekanan Hi-Tech Architecture). Universitas Pandanaran, 1.

19. Utsman Syah Amrullah, Satworo Adiwidodo, Riyanto Heri Nugroho, Haris Puspito Buwono, \& Elka Faisal. (2020). Pengadaan fasilitas olahraga badminton bagi taman pendidikan al-quran ahlussunnah waljama'ah rt 05 rw 03 Kel. Tlogomas, Lowokwaru, Malang. Jurnal Pengabdian Polinema Kepada Masyarakat, 7(1). https://doi.org/10.33795/jppkm.v7i1.20

20. Valianto, B., \& M. Sirait, D. H. (2018). Survei minat masyarakat untuk menggunakan fasilitas olahraga di Universitas Negeri Medan. Sains Olahraga: Jurnal Ilmiah Ilmu Keolahragaan, 1(2). https://doi.org/10.24114/so.v1i2.7786 